\title{
Analisis Efektivitas Pengikat Fosfat Tablet Kalsium Karbonat yang Dikunyah Dibandingkan yang Ditelan Utuh pada Pasien Penyakit Ginjal Kronis Dengan atau Tanpa Gangguan Saluran Cerna
}

\author{
Galuh Nawang Prawesti ${ }^{1}$, R. Moh. Yogiantoro ${ }^{2}$, Gunawan Widodo ${ }^{3}$, Anita Purnamayanti ${ }^{4}$ \\ ${ }^{1}$ Fakultas Farmasi, Universitas Katolik Widya Mandala Catholic Surabaya, Jalan Raya \\ Kalisari Selatan No.1, Surabaya, Indonesia \\ ${ }^{2}$ Fakultas Kedokteran Universitas Airlangga, Surabaya \\ ${ }^{3}$ Fakultas Kedokteran Universitas Airlangga, Surabaya dan Spesialis \\ Ilmu Penyakit Dalam di RSU Haji, Surabaya \\ ${ }^{4}$ Fakultas Farmasi Universitas Surabaya
}

\begin{abstract}
Tablet pengikat fosfat kalsium karbonat harus dikunyah pada pasien Penyakit Ginjal Kronis (PGK) dengan komplikasi gangguan mineral dan tulang, namun sebagian menelan utuh. Komplikasi gangguan saluran cerna mempengaruhi efektivitas obat. Tujuan penelitian menganalisis efektivitas kalsium karbonat dikunyah dibandingkan ditelan utuh pada pasien PGK dengan atau tanpa gangguan saluran cerna. Penelitian quasi eksperimental prospektif, desain non-inferiority dilakukan 28 Mei-22 Agustus 2012, 22 sampel (PGK stage 3-5), 14 laki-laki, 8 perempuan, dibagi 4 kelompok (1: memiliki gangguan saluran cerna dan menelan utuh tablet kalsium karbonat, 2 : memiliki gangguan dan mengunyah tablet, 3 : tanpa gangguan dan menelan utuh tablet, 4 : tanpa gangguan dan mengunyah tablet, serta semua digunakan bersamaan makan). Awal dan akhir enam minggu periode penelitian diukur kadar kalsium dan fosfat, setiap dua minggu diukur kepatuhannya dengan Morisky questionnaire dan pill count. Hasil penelitian tidak menunjukkan perbedaan signifikan peningkatan kadar kalsium, kecuali kelompok 1 dibandingkan $3(p=0,027)$, penurunan kadar fosfat $(p=0,724 ; 0,089 ; 0,089$; $0,414 ; 0,569 ; 1,000)$ dan nilai produk kalsium-fosfat $(p=1,000 ; 0,308 ; 0,186 ; 0,414 ; 0,425 ; 0,728)$. Kesimpulannya cara penggunaan obat dan gangguan saluran cerna tidak berpengaruh signifikan terhadap efektivitas tablet kalsium karbonat.
\end{abstract}

Kata kunci: kalsium karbonat, efektivitas, pengikat fosfat, dikunyah, ditelan utuh, gangguan saluran cerna

\section{Effectiveness Analysis Comparation of Chewed and Whole Swallowed Calcium Carbonate Tablet as A Phosphate Binder in Chronic Kidney Disease Patients with or without Gastrointestinal Disorders}

Chronic Kidney Disease (CKD) patient with Mineral and Bone Disorder complication have to chew calcium carbonate tablet as a phosphate binder, but infact, patient swallow it in a whole. Gastrointestinal (GI) disorders can affect the efficacy of medicine. This study aims to analyze the effectiveness comparation of chewed and whole swallowed calcium carbonate tablet in CKD patients with or without gastrointestinal disorders. This prospective quasi experimental study with non-inferiority design was conducted on May $28^{\text {th }}$ to August $22^{\text {nd }} 2012$, with 22 sample (stage 3-5 CKD), 14 men, 8 women, divided into 4 groups ( 1 st: patients with GI disorder and whole swallowed calcium carbonate, $2^{\text {nd: }}$ with $\mathrm{Gl}$ disorders and chewed tablet, $3^{\text {rd: }}$ without Gl disorders and whole swallowed tablet, $4^{\text {th }}$ group: without $\mathrm{Gl}$ disorders and chewed tablet, all tablet are used with meal). Before and after the $6^{\text {th }}$ week research period, calcium and phosphate blood levels measurements had been taken, adherence had been measured every two weeks using the Morisky questionnaire and pill count. The results showed that there was no significant difference in the increased of calcium levels, except for group 1 compared to group $3(p=0.027)$, the decreased phosphate levels $(p=0.724 ; 0.089 ; 0.089 ; 0.414 ; 0.569 ; 1.000)$ and the value of the product calcium-phosphate ( $p=1.000 ; 0.308 ; 0.186 ; 0.414 ; 0.425 ; 0.728)$. The conclusion is that the way to use the medicine and the states of gastrointestinal disorders did not significantly influence the effectiveness of calcium carbonate tablet.

Keywords: calcium carbonate, effectiveness, phosphate binder, chewed, whole swallowed, gastro-intestinal disorder

${ }^{*}$ Corresponding author: Fakultas Farmasi Universitas Katolik Widya Mandala Surabaya, Jl. Raya Kalisari Selatan No. 1 Surabaya, e-mail: galuh@ukwms.ac.id 


\section{PENDAHULUAN}

Penyakit Ginjal Kronis (PGK) merupakan masalah kesehatan yang telah mendunia dan diperkirakan telah dialami oleh 5-10 \% populasi dunia. Penyakit Ginjal Kronis terbagi dalam 5 tingkatan yang dibedakan berdasarkan nilai LFG serta tingkat keparahan penyakit, dimana semakin lama kondisi penyakit pasien dapat menjadi semakin parah serta menimbulkan berbagai gejala serta komplikasi hingga akhirnya pasien dapat menderita Penyakit Ginjal Terminal (PGT) ataupun kematian. Komplikasi PGK yang umumnya terjadi pada pasien PGK adalah anemia, hipertensi, pruritus, malnutrisi, gangguan pada saluran cerna, gangguan mineral dan tulang (Qunibi et al., 2011; Ashley dan Morlidge, 2008; O'Callaghan, 2000).

Gangguan mineral dan tulang umum terjadi pada pasien PGK dan berhubungan dengan peningkatan angka kesakitan serta kematian (Hutchison, 2009). Dalam menangani masalah hiperfosfatemia ini terdapat tiga kunci utama terapi yaitu pembatasan asupan fosfat, pemberian obat-obatan pengikat fosfat (oral phosphate binder) dan dialisis yang adekuat (Hutchison, 2009). Berbagai macam obat pengikat fosfat yang tersedia di pasaran di antaranya adalah garam alumunium, kalsium karbonat, kalsium asetat, garam magnesium, sevelamer dan lanthanum karbonat (Hutchison, 2009). Di Indonesia, suplemen kalsium merupakan tablet pengikat fosfat yang paling banyak digunakan. Salah satu suplemen kalsium yang masuk dalam Daftar Plafon Harga Obat (DPHO) PT. ASKES Indonesia dan Formularium obat JAMKESMAS serta JAMKESDA adalah kalsium karbonat (ASKES, 2010).

Kalsium karbonat yang diberikan kepada pasien ASKES, JAMKESMAS dan JAMKESDA adalah $\operatorname{Calos}^{\circledR}$ dan Osteocal ${ }^{\circledR}$, dimana dalam penggunaannya, kedua tablet tersebut perlu dikunyah karena tablet yang diberikan telah didesain sedemikian rupa agar memberikan efek yang maksimal dalam bentuk chewable. Tablet chewable didesain secara khusus agar terdisintegrasi secara mekanis di mulut, sehingga akan mempercepat onset aksi dari obat tersebut (Williams et al., 2008). Menurut pustaka, tablet kalsium karbonat yang dikunyah memiliki absorbsi yang lebih baik dibandingkan sediaan effervescent (Ekman et al., 1991). Dalam kenyataannya penggunaan tablet ini tidak sesuai dengan desain yang telah dibuat, yaitu pasien yang cenderung menelan utuh tablet tersebut. Sesuai karakteristik kalsium karbonat, tablet ini memiliki rasa yang tidak enak (unpalatable), selain itu dapat menimbulkan efek samping pada saluran pencernaan, seperti menghasilkan gas dalam perut (flatulence) dan konstipasi. Pada pasien PGK, komplikasi terhadap saluran cerna seperti mual karena tingginya kadar urea di dalam tubuh dan resiko kejadian stress ulcer sering terjadi (Ashley dan Morlidge, 2008; Medscape Pharmacist education, 2010). Menurut teori, rasa tidak nyaman yang menyerang saluran cerna dapat menurunkan penerimaan dan kepatuhan pasien terhadap obat, apalagi ditambah dengan cara pemberian obat yang harus dikunyah terlebih dahulu dapat semakin menurunkan kepatuhan pasien. Pada kondisi dimana kepatuhan pasien berkurang, maka pasien umumnya langsung menelan utuh tablet kalsium karbonat, maka perlu diteliti efektivitas pengikat fosfat tablet kalsium karbonat yang dikunyah dibandingkan ditelan utuh pada pasien PGK (Hutchison, 2009; Sweetman et al., 2007; Arenas et al., 2010).

Kalsium karbonat, seperti halnya calcium based phosphate binder yang lain, efektivitasnya ditentukan oleh waktu pemberian, karena tablet kalsium karbonat akan memberikan efek maksimal, jika digunakan bersamaan dengan makan, agar dapat mengikat fosfat yang terkandung dalam makanan yang dicerna oleh pasien PGK, dan selanjutnya membentuk senyawa kompleks kalsium fosfat yang tidak larut sehingga fosfat dari makanan tidak diabsorbsi oleh tubuh namun diekskresikan dan tidak meningkatkan kadar fosfat dalam darah (Indian Health Service National Pharmacy and Therapeutics Committee, 2010; Coladonato, 2005; National Institute of Diabetes and Digestive and Kidney Diseases, 2005). Oleh karena itu perlu diadakan penelitian mengenai Analisis Efektivitas Pengikat Fosfat Tablet Kalsium Karbonat yang Dikunyah Dibandingkan yang Ditelan Utuh pada Pasien Penyakit Ginjal Kronis dengan atau Tanpa Gangguan Saluran Cerna. Dua buah hipotesis yang terdapat dalam penelitian ini adalah efektivitas pengikat fosfat tablet kalsium karbonat yang ditelan utuh bersamaan makan tidak lebih buruk dibandingkan yang dikunyah bersamaan makan dan juga bahwa efektivitas pengikat fosfat tablet kalsium karbonat pada pasien dengan gangguan saluran cerna tidak lebih buruk dibandingkan pasien tanpa gangguan saluran cerna.

\section{METODE PENELITIAN}

Penelitian ini adalah penelitian kuantitatif dengan pendekatan eksperimental prospektif selama enam minggu serta desain penelitian noninferiority. Tahap ini bertujuan untuk menganalisis efektivitas pengikat fosfat tablet kalsium karbonat dari keempat kelompok terapi yaitu kelompok 1 (sampel penelitian dengan gangguan saluran cerna dan menggunakan tablet kalsium karbonat dengan ditelan utuh), kelompok 2 (sampel penelitian dengan gangguan saluran cerna dan menggunakan tablet kalsium karbonat dengan dikunyah), kelompok 3 (sampel penelitian tanpa gangguan saluran cerna dan menggunakan 
tablet kalsium karbonat dengan ditelan utuh) dan kelompok 4 (sampel penelitian tanpa gangguan saluran cerna dan menggunakan tablet kalsium karbonat dengan dikunyah).

Populasinya adalah pasien PGK tahap 3,4,5, dan sedang menjalani rawat jalan di RSU Haji Surabaya dari Mei-September 2012, yang sesuai dengan kriteria penelitian yaitu kriteria inklusi merupakan pasien berusia di atas 18 tahun, telah didiagnosis mengalami PGK tahap 3, 4 dan 5 dan sedang menjalani rawat jalan di poli penyakit dalam RSU Haji Surabaya, memiliki kadar $\mathrm{PO}_{4}>4,6 \mathrm{mg} / \mathrm{dL}(1,48 \mathrm{mmol} / \mathrm{L})$ dan $\mathrm{Ca}<8 \mathrm{mg} / \mathrm{dL}$ $(2,5 \mathrm{mmol} / \mathrm{L})$, belum pernah mendapatkan terapi tablet pengikat fosfat, memenuhi kriteria kepatuhan sedang dan tinggi menurut Morisky Questionnaire, bersedia mengikuti penelitian dengan mengisi statement of consent form. Sedangkan kriteria eksklusi adalah pasien yang mengalami kondisi mengancam jiwa dan hamil. Kriteria Drop Out adalah pasien yang mengalami kondisi ataupun efek samping obat yang mengancam jiwa, meninggal, mengalami serangan akut selama penelitian berlangsung dan jika pasien mengundurkan diri.

Jumlah sampel adalah jumlah sampel minimum yang dapat digunakan dalam penelitian klinis yaitu 12 untuk setiap kelompok uji (Thomas, 2000), sehingga untuk empat kelompok terapi sebesar 48 pasien. Penggolongan pasien untuk masing-masing kelompok dilakukan dengan metode randomisasi sederhana dan dapat dilihat pada Gambar 1. Teknik pengambilan sampel adalah total sampling sampai terpenuhinya sampel dengan jumlah minimal yaitu 48 pasien.

Data efektivitas didapat dari hasil pemeriksaan laboratorium pada awal dan akhir periode penelitian terhadap kadar kalsium, fosfat dan nilai perkalian produk kalsium-fosfat. Data hasil kepatuhan minum obat didapat dari hasil Morisky questionnaire dan pill count serta efektivitas penurunan kadar (kalsium, fosfat dan nilai produk kalsium-fosfat). Penggunaan morisky questionnaire untuk pemantauan kepatuhan dilakukan sebanyak empat kali yaitu di awal sebagai proses seleksi pasien dan tiga kali post questionnaire yang diberi jangka waktu tiap dua minggu sebagai alat untuk melakukan pemantauan kepatuhan, pill count dilakukan sebanyak tiga kali, bersamaan dengan dilakukannya pemantauan kepatuhan menggunakan Morisky questionnaire. Pemantauan kepatuhan juga dilakukan melalui interview terhadap pasien dengan berkunjung langsung ke rumah pasien serta meminta bantuan kepada keluarga terdekat pasien untuk memastikan bahwa obat diminum dengan tepat oleh pasien. Interview mengenai efek samping juga dilakukan kepada pasien.

Analisis statistik yang digunakan adalah analisis deskriptif dan inferensial. Analisis statistik deskriptif digunakan untuk karakteristik awal sampel penelitian dan data tingkat kepatuhan minum obat, sedangkan efektivitas pengikat fosfat tablet kalsium karbonat yang dikunyah dibandingkan ditelan utuh pada pasien PGK dengan atau tanpa gangguan saluran cerna menggunakan analisis inferensial yaitu Uji Mann Whitney dan Uji Chi Square, pengujian hipotesis menggunakan Uji $\mathrm{t}$ berpasangan atau uji Wilcoxon Signed Ranks Test ; Uji t tidak berpasangan atau dengan uji Mann Whitney dan Uji One Way ANOVA atau uji Kruskal Wallis, hasil penilaian kepatuhan pasien menggunakan Morisky Questionnaire dan pill count dianalisis dengan uji Repeated measure, uji t berpasangan atau uji Wilcoxon test, lalu dilakukan analisis korelasi antara data pill count dan Morisky Questionnaire. Proposal penelitian yang telah disusun diajukan kepada pihak rumah sakit kemudian dikaji oleh Komisi Etik Rumah Sakit. Sebelum proses pengambilan data, pasien akan mendapatkan penjelasan tentang tujuan, prosedur, manfaat, resiko penelitian dan tindakan pengamanannya serta mendapatkan jaminan kerahasiaan identitas. Sebagai tanda kesediaan partisipasi dalam penelitian ini, pasien diminta untuk menandatangani formulir persetujuan partisipasi dalam penelitian (formulir statement of consent).

\section{HASIL DAN PEMBAHASAN}

Profil rekrutmen pasien dengan gangguan kadar kalsium dan fosfat pada penyakit ginjal kronik (PGK) yang dilibatkan dalam penelitian ini dapat dilihat pada Gambar 1.

Data kepatuhan berdasar pill count yaitu 22,73\% pasien dengan kepatuhan tinggi, 4,55\% pasien dengan kepatuhan meningkat, 9,10\% pasien dengan kepatuhan berkurang dan $63,64 \%$ pasien yang tidak patuh ; berdasarkan Morisky Questionnaire ada $27,27 \%$ pasien dengan kepatuhan tinggi, 13,64 pasien dengan kepatuhan meningkat, 4,55\% pasien dengan kepatuhan menurun dan 54,55\% pasien yang tidak patuh ; serta berdasar kadar kalsium, fosfat dan nilai produk kalsium-fosfat ada $63,64 \%$ pasien dengan kepatuhan tinggi, 4,55\% pasien dengan kepatuhan meningkat, 4,55\% pasien dengan kepatuhan berkurang dan $27,27 \%$ pasien yang tidak patuh.

Data perubahan kadar kalsium rata-rata sebelum dan sesudah terapi : kelompok 1 dari $8,86 \mathrm{mg} / \mathrm{dL}$ ke 10,40 mg/dL ; kelompok 2 dari 8,69 mg/dL ke 9,76 mg/dL ; kelompok 3 dari 9,18 $\mathrm{mg} / \mathrm{dL}$ ke 9,68 mg/dL ; kelompok 4 dari 8,86 $\mathrm{mg} / \mathrm{dL}$ ke $9,74 \mathrm{mg} / \mathrm{dL}$. Kadar fosfat rata-rata sebelum dan sesudah terapi kelompok 1 dari 7,18 $\mathrm{mg} / \mathrm{dL}$ menjadi $3,73 \mathrm{mg} / \mathrm{dL}$; kelompok 2 dari $6,57 \mathrm{mg} / \mathrm{dL}$ menjadi $3,43 \mathrm{mg} / \mathrm{dL}$; kelompok 3 dari $6,93 \mathrm{mg} / \mathrm{dL}$ menjadi $5,68 \mathrm{mg} / \mathrm{dL}$ dan kelompok 4 dari $6,34 \mathrm{mg} / \mathrm{dL}$ menjadi $5,10 \mathrm{mg} / \mathrm{dL}$. Nilai produk kalsium-fosfat sebelum dan sesudah 
terapi kelompok 1 dari $63,82 \mathrm{mg}^{2} / \mathrm{dL}^{2}$ menjadi $38,65 \mathrm{mg}^{2} / \mathrm{dL}^{2}$; kelompok 2 dari $55,64 \mathrm{mg}^{2} / \mathrm{dL}^{2}$ menjadi $33,20 \mathrm{mg}^{2} / \mathrm{dL}^{2}$; kelompok 3 dari 63,72 $\mathrm{mg}^{2} / \mathrm{dL}^{2}$ menjadi $54,08 \mathrm{mg}^{2} / \mathrm{dL}^{2}$ dan kelompok 4 dari $56,66 \mathrm{mg}^{2} / \mathrm{dL}^{2}$ menjadi $59,84 \mathrm{mg}^{2} / \mathrm{dL}^{2}$.

Tabel 1. Tabel Karakteristik Awal Sampel Penelitian.

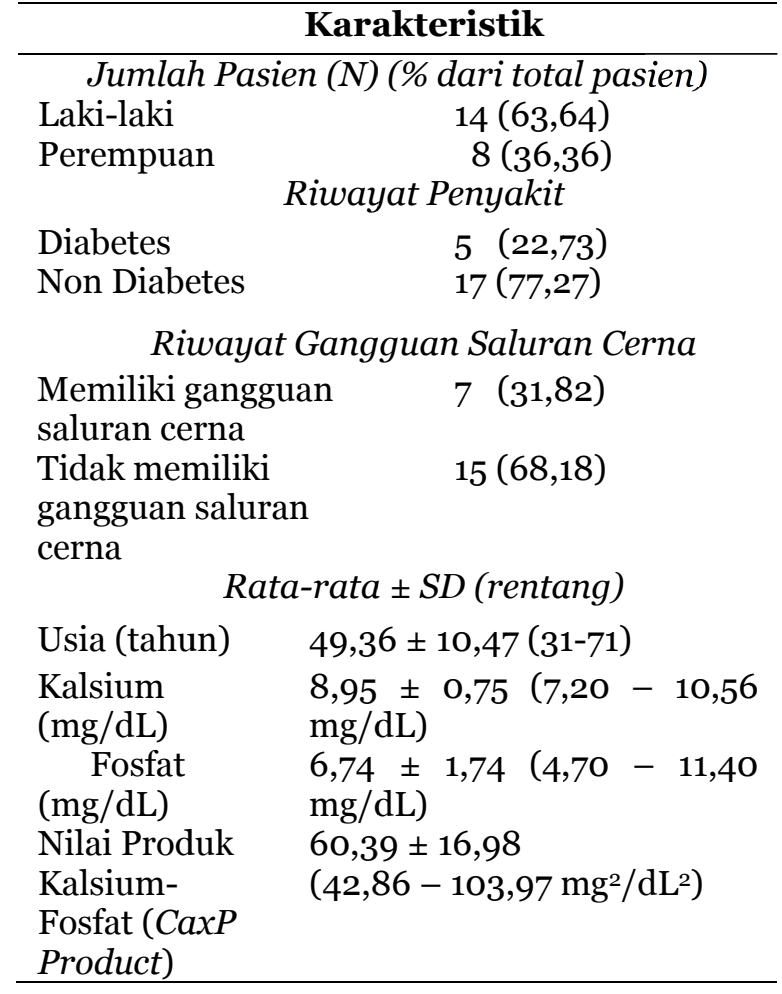

Analisis efektivitas tablet kalsium karbonat dilihat dari peningkatan kadar kalsium, penurunan kadar fosfat dan nilai produk kalsiumfosfat. Uji Mann Whitney dan uji alternatif lain yaitu Chi square tidak menunjukkan perbedaan signifikan, kecuali saat peningkatan kadar kalsium dibandingkan antara kelompok 1 dan $3(\mathrm{p}=$ 0,027).

Pengujian hipotesis kadar kalsium awalakhir dengan uji $\mathrm{t}$ berpasangan (karena data memiliki distribusi normal) tidak menunjukkan hasil signifikan kecuali pada kelompok 4 ( $\mathrm{p}=$ 0,022), pengujian kadar fosfat dan nilai produk kalsium-fosfat awal-akhir dengan uji Wilcoxon Signed Ranks Test (karena data memiliki distribusi tidak normal) tidak menunjukkan perbedaan signifikan pada semua kelompok, pengujian kadar kalsium, fosfat dan nilai produk kalsium-fosfat akhir antar kelompok dengan uji t tidak berpasangan antar 2 kelompok (karena data memiliki distribusi normal) ataupun dengan uji one way ANOVA antar semua kelompok (untuk menguji semua variabel yang terdapat di dalam penelitian) tidak menunjukkan perbedaan signifikan.

Pengujian tingkat kepatuhan minum obat dengan uji Repeated Measure terhadap hasil
Morisky questionnaire tiap dua minggu tidak menunjukkan perbedaan yang signifikan, dengan uji Wilcoxon Signed Ranks Test (karena data awal hasil Kuesioner Morisky memiliki distribusi tidak normal) memberikan hasil tidak signifikan. Uji korelasi dengan Pearson (karena kedua data memiliki distribusi normal) ataupun Spearman (karena salah satu data memiliki distribusi yang tidak normal) antara Morisky questionnaire dan pill count menunjukkan korelasi minus.

Menurut data deskriptif pasien, pada penelitian ini ditemukan penyebab PGK lebih banyak adalah non DM $(77,27 \%)$. Hal ini dapat dipengaruhi oleh beberapa faktor penyebab yaitu penentuan riwayat penyakit pasien DM hanya melalui pengamatan terhadap rekam medis pasien, pada saat penelitian dilakukan bersamaan waktunya saat jumlah pasien DM yang melakukan rawat jalan sedikit dan ada pasien PGK DM yang tidak memenuhi kriteria inklusi penelitian.

Pada penelitian ini, sebagian besar sampel penelitian pada keempat kelompok terapi $(1,2,3$ dan 4) mengalami gangguan mineral dan tulang serta memiliki tanda-tanda hiperfosfatemia namun rata-rata data baseline hasil pemeriksaan kadar kalsium masuk dalam rentang normal, sementara rata-rata nilai produk kalsium-fosfat menunjukkan bahwa sampel penelitian memiliki tanda-tanda komplikasi gangguan mineral dan tulang. Dengan data tersebut, seharusnya sampel penelitian mendapat tablet pengikat fosfat yaitu Kalsium Karbonat (Calos $($ ), untuk pasien yang memiliki kadar kalsium tinggi sebaiknya direkomendasikan penggunaan Lanthanum Karbonat, Sevelamer ataupun tablet pengikat fosfat lainnya yang tidak mengandung kalsium (PERNEFRI, 2009).

Berdasarkan penetapan kriteria kepatuhan yang telah dilakukan, tingkat ketidakpatuhan pasien PGK pada penelitian ini sesuai dengan pustaka, walaupun ditetapkan berdasarkan kriteria yang berbeda dan tiap metode memiliki kelebihan serta kelemahan masing-masing.

Pada penelitian ini ketidakpatuhan sampel penelitian disebabkan karena faktor dari dalam yaitu kepercayaan terhadap pengobatan dan juga rasa malas untuk menggunakan obat yang terlalu banyak. Faktor luar yang dapat mempengaruhi adalah faktor obat, faktor kondisi sampel penelitian yang tidak dapat diperkirakan sebelumnya, pasien kadang terlupa membawa obat dan juga tidak dapat menggunakan obat sesuai aturan, kondisi sampel yang masih aktif bekerja, pergi ke luar kota sekali waktu dan juga puasa. Faktor dukungan keluarga, orang terdekat dan tenaga kesehatan yang terlibat langsung dalam proses pengobatan sampel penelitian juga memiliki pengaruh.

Uji Mann Whitney dan Chi square telah dilakukan dan hanya menunjukkan suatu perbedaan yang signifikan saat kelompok 1 
dibandingkan dengan kelompok 3. Perbandingan kedua kelompok ini dapat menunjukkan bahwa terdapat kemungkinan adanya pengaruh adanya gangguan saluran cerna terhadap peningkatan kadar kalsium. Menurut uji t berpasangan terjadi peningkatan yang signifikan pada peningkatan kadar kalsium sebelum dan sesudah terapi pada kelompok 4 namun, saat dibandingkan dengan kelompok yang lain menggunakan uji Mann Whitney dan Chi square ternyata tidak memiliki perbedaan yang signifikan. Pengaruh gangguan saluran cerna yang terjadi saat kelompok 1 dan kelompok 3 dibandingkan, menurut rata-rata peningkatan kadar kalsium, menunjukkan pada kelompok 1 terjadi peningkatan lebih tinggi dibanding kelompok 3 .

Menurut tabel Ranks hasil uji Mann Whitney, kelompok 3 memiliki Mean Rank yang lebih rendah dibandingkan kelompok 1, karena peningkatan kadar kalsium pada kelompok 3 tidak sebesar yang terjadi pada kelompok 1 . Peningkatan lebih tinggi ini berkaitan dengan motilitas saluran cerna sampel. Pada pasien dengan gangguan saluran cerna, motilitas yang lebih lambat dapat terjadi, sehingga kemungkinan tablet kalsium karbonat dapat tertinggal lebih lama di usus, dimana terjadi absorbsi kalsium secara aktif dapat terjadi lebih lama, sehingga kadar kalsium yang terabsorbsi lebih banyak dan dapat meningkatkan kadar kalsium dalam darah lebih tinggi dibanding pasien tanpa gangguan saluran cerna (kelompok 3).

Peningkatan kadar kalsium yang signifikan terjadi pada pasien yang tidak memiliki gangguan saluran cerna dan menggunakan tablet kalsium karbonat dengan cara dikunyah terjadi karena pada pasien tanpa gangguan saluran cerna, absorbsi kalsium yang berlangsung di usus berjalan dengan baik dan cara penggunaan tablet kalsium karbonat dengan cara dikunyah, memperluas permukaan tablet sehingga dengan cepat kalsium dapat terabsorbsi oleh usus dan meningkatkan kadar kalsium dalam darah (Dipiro et al., 2008).

Analisis penurunan kadar fosfat terhadap semua kelompok telah dilakukan melalui uji Mann Whitney dan Chi Square, dan dari kedua uji tersebut tidak menunjukkan perbedaan yang signifikan antar semua kelompok. Hal ini menunjukkan bahwa keempat variabel bebas yang diteliti (gangguan saluran cerna dan tidak, ditelan utuh dan dikunyah) tidak memberikan pengaruh yang signifikan melalui indikator kadar fosfat. Jika hanya melihat data deskriptif (tanpa melihat kemaknaan statistik), penurunan kadar fosfat pada kelompok 1 dan 2 (kelompok dengan gangguan saluran cerna) lebih besar dibandingkan kelompok 3 dan 4 (kelompok tanpa gangguan saluran cerna).

Hal tersebut dapat dijelaskan yaitu pada pasien PGK dengan gangguan saluran cerna, motilitas saluran cerna akan terganggu, makanan yang tercerna dalam tubuh akan tinggal lebih lama di saluran cerna, sehingga memungkinkan tablet kalsium karbonat untuk mengikat lebih banyak fosfat yang terkandung dalam makanan, tablet kalsium karbonat juga akan tinggal lebih lama dalam saluran cerna karena gangguan motilitas tersebut sehingga efektivitas pengikatan fosfatnya lebih tinggi dibandingkan pasien tanpa gangguan saluran cerna.

Pada penelitian ini terdapat kelemahan yaitu kekuatan penelitian yang kurang, baik dari segi jumlah sampel yang kurang memenuhi jumlah minimal sampel dan waktu penelitian yang kurang sehingga menurunkan power penelitian. Selain itu hal yang dapat mempengaruhi keberhasilan terapi pada penelitian ini termasuk tingkat kepatuhan pasien yang sangat rendah terhadap obat, diet pembatasan asupan fosfat yang tidak dilaksanakan oleh pasien dikarenakan kurangnya pengetahuan pasien dan juga pengaruh dari adekuasi hemodalisis (HD) yang dilakukan, namun pada penelitian ini tidak diteliti mengenai adekuasi HD (Karamanidou et al., 2008).

Menurut pustaka desain tablet chewable yang telah dibuat oleh perusahaan farmasi memiliki tujuan khusus agar terdisintegrasi secara mekanis di mulut, sehingga mempercepat onset aksi dari obat tersebut (Williams et al., 2008). Dalam penggunaannya seringkali tidak sesuai dengan desain chewable yang telah dibuat, namun hal ini telah diantisipasi oleh perusahaan farmasi yang bersangkutan dengan mengikuti suatu persyaratan uji yang sama dengan tablet pada umumnya dan perusahaan farmasi tersebut harusnya sudah melakukan prosedur pembuatan obat sesuai standar karena sudah mengikuti CPOB (Cara Pembuatan Obat yang Baik), sehingga jika ada penggunaan obat yang tidak sesuai aturan (misalnya ditelan) maka, efektivitas yang diberikan oleh obat tersebut akan sama dengan efektivitas dari tablet chewable (CDER, 2000).

Perubahan nilai produk kalsium-fosfat sebelum dan sesudah terapi pada masing-masing kelompok terapi (1, 2, 3 dan 4) dianalisis dengan menggunakan uji statistik Wilcoxon signed rank test, uji Mann Whitney dan Chi square, uji t tidak berpasangan, Uji One Way ANOVA dan tidak menunjukkan perbedaan yang signifikan.

\section{KESIMPULAN DAN SARAN}

Kesimpulan dari penelitian ini adalah cara penggunaan tablet kalsium karbonat baik dengan cara ditelan utuh ataupun dikunyah bersamaan makan dan gangguan saluran cerna yang diderita tidak berpengaruh secara signifikan terhadap efektivitas pengikat fosfat tablet kalsium karbonat yang digambarkan dengan kadar kalsium, fosfat ataupun nilai produk kalsium-fosfat (CaxP 


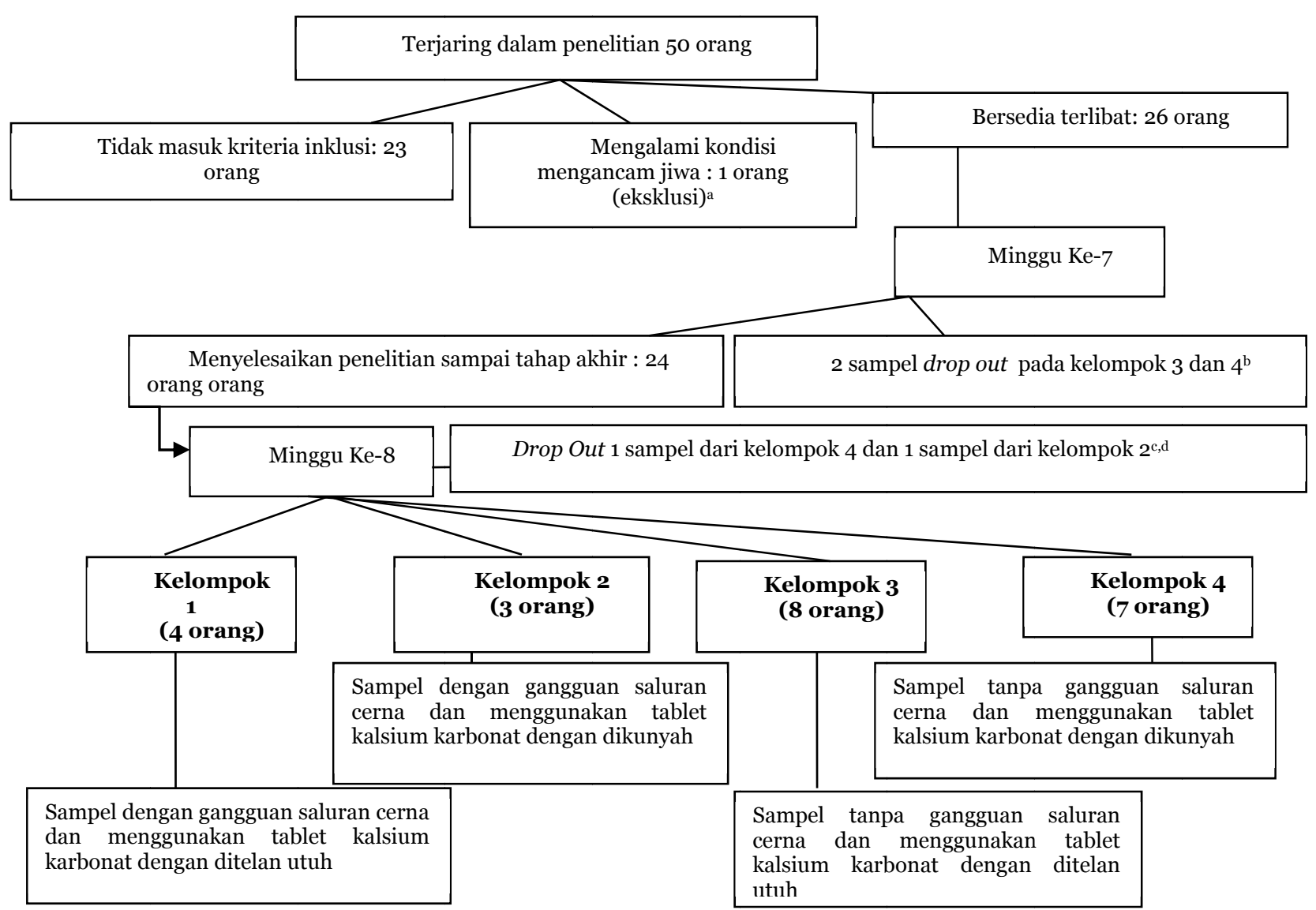

GAMBAR 1. Profil Rekrutmen Pasien dengan Gangguan Kadar Kalsium dan Fosfat pada Penyakit Ginjal Keterangan:

\section{Kronik.}

a. 1 pasien dieksklusi karena mengalami kondisi yang mengancam jiwa

b. 2 pasien sebagai sampel penelitian pada kelompok 3 dan 4 drop out karena menolak untuk melanjutkan penelitian

c. 1 pasien sebagai sampel penelitian drop out dari kelompok 4 karena pindah ke kelompok 3 dengan alasan pasien mengeluh tidak nyaman jika menggunakan tablet kalsium karbonat dengan cara dikunyah dan peneliti tidak memberikan wash-out period

1 pasien sebagai sampel penelitian drop out dari kelompok 2 karena tidak menggunakan obat sesuai dengan petunjuk peneliti (dikunyah) tetapi dengan cara dikapsul

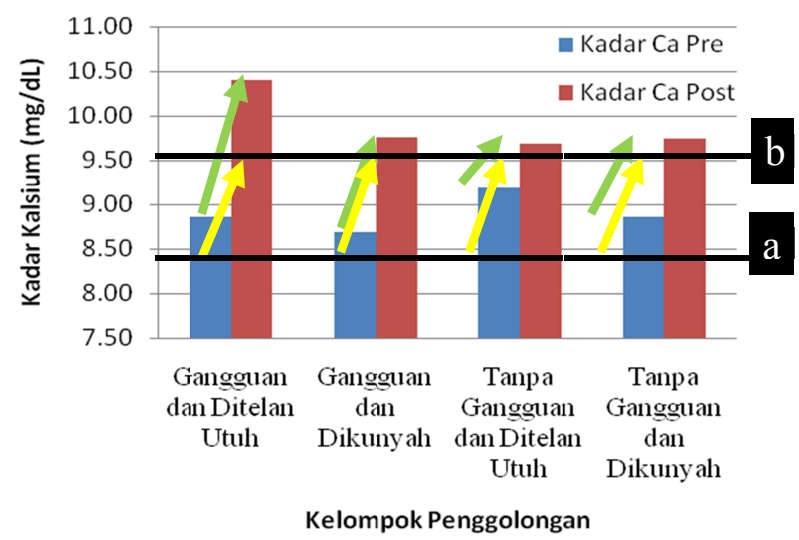

GAMBAR 2. Kadar Kalsium Awal-Akhir Penelitian dengan Terapi Kalsium Karbonat.

Keterangan Gambar 2 : a-b : target kadar kalsium



GAMBAR 3. Kadar Fosfat Awal-Akhir Penelitian dengan Terapi Kalsium Karbonat.

Keterangan:

a-b $\quad$ : target kadar fosfat untuk tahap 3-5 


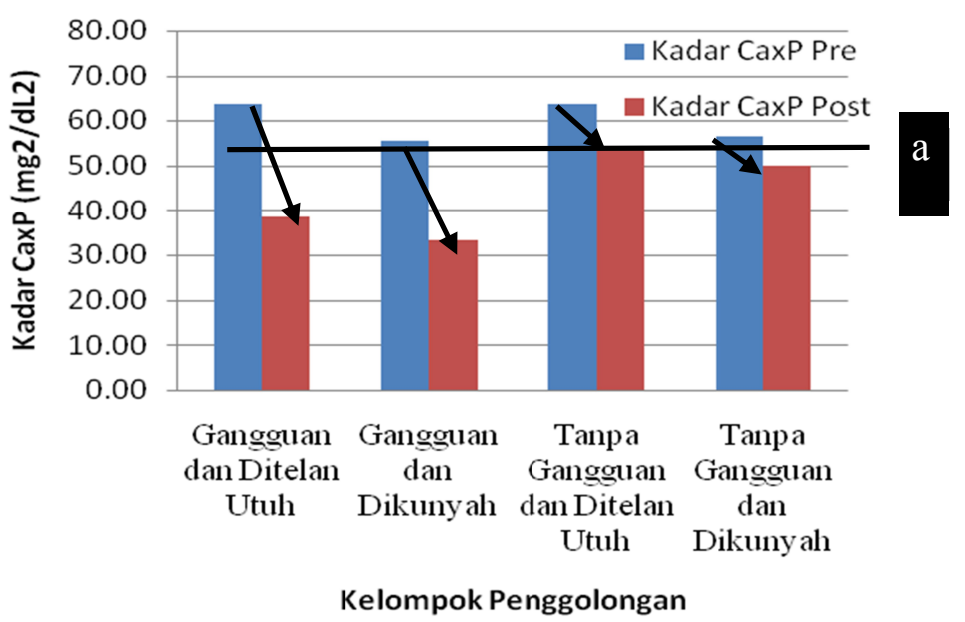

GAMBAR 4. Nilai Produk Kalsium-Fosfat ( $C a x$ P Product) Awal-Akhir Penelitian dengan Terapi Kalsium Karbonat. Keterangan:

a $\quad$ : Batas nilai normal produk kalsium-fosfat (Ca $x$ P Product)

TABEL 2. Tabel Rangkuman Hasil Uji Statistik

Uji Mann Whitney (nilai p)

\begin{tabular}{|c|c|c|c|c|c|c|}
\hline \multirow{2}{*}{ Kelompok } & \\
\hline & $\begin{array}{c}\text { Peningkat- } \\
\text { an Ca }\end{array}$ & $\begin{array}{c}\text { Peningkat- } \\
\text { an Ca (\%) }\end{array}$ & $\begin{array}{l}\text { Penurun- } \\
\text { an } \mathrm{PO}_{4}\end{array}$ & $\begin{array}{c}\text { Penurun- } \\
\text { an } \mathrm{PO}_{4} \\
(\%)\end{array}$ & $\begin{array}{l}\text { Penurun- } \\
\text { an CaxP }\end{array}$ & $\begin{array}{c}\text { Penurunan } \\
\text { CaxP (\%) }\end{array}$ \\
\hline 1 dan 2 & 0,289 & 0,724 & 0,724 & 0,289 & 1,000 & 1,000 \\
\hline 1 dan 3 & 0,027 & 0,027 & 0,089 & 0,074 & 0,308 & 0,308 \\
\hline 1 dan 4 & 0,571 & 0,571 & 0,089 & 0,186 & 0,186 & 0,345 \\
\hline 2 dan 3 & 0,837 & 0,837 & 0,414 & 0,414 & 0,414 & 0,221 \\
\hline 2 dan 4 & 0,909 & 0,909 & 0,569 & 0,425 & 0,425 & 0,305 \\
\hline 3 dan 4 & 0,246 & 0,203 & 1,000 & 0,908 & 0,728 & 0,728 \\
\hline Kelompok & $\begin{array}{l}\text { Peningkat- } \\
\text { an Ca }\end{array}$ & $\begin{array}{l}\text { Peningkat- } \\
\text { an Ca (\%) }\end{array}$ & $\begin{array}{c}\text { Uji Chi Squc } \\
\text { Penurun- } \\
\text { an } \mathrm{PO}_{4}\end{array}$ & $\begin{array}{l}\text { re (nilai p) } \\
\text { Penurun- } \\
\text { an } \mathrm{PO}_{4} \\
(\%)\end{array}$ & $\begin{array}{l}\text { Penurun- } \\
\text { an CaxP }\end{array}$ & $\begin{array}{c}\text { Penurunan } \\
\text { CaxP (\%) }\end{array}$ \\
\hline 1 dan 2 & 1,000 & 1,000 & 1,000 & 1,000 & 1,000 & 1,000 \\
\hline 1 dan 3 & 1,000 & 1,000 & 0,091 & 0,333 & 0,091 & 0,091 \\
\hline 1 dan 4 & 1,000 & 1,000 & 0,491 & 1,000 & 0,109 & 0,491 \\
\hline 2 dan 3 & 0,491 & 0,491 & 0,273 & 0,273 & 0,273 & 0,273 \\
\hline 2 dan 4 & 1,000 & 1,000 & 1,000 & 1,000 & 0,300 & 1,000 \\
\hline 3 dan 4 & 1,000 & 1,000 & 0,467 & 0,467 & - & 0,467 \\
\hline
\end{tabular}

Product).

Saran dari peneliti yaitu agar tenaga kesehatan dapat merekomendasikan penggunaan tablet pengikat fosfat kalsium karbonat yang sesuai dengan preferensi pasien, sebaiknya dilakukan penelitian lanjutan dengan jumlah sampel yang lebih banyak dan periode penelitian yang lebih panjang dan mengurangi confounding variable yang ada (dengan pembatasan asupan fosfat) agar memberikan gambaran yang sesuai dengan populasi penelitian, tenaga kesehatan harusnya meningkatkan konseling dan edukasi pencegahan gangguan mineral dan tulang pada PGK dengan pembatasan asupan fosfat, penggunaan tablet pengikat fosfat, serta pemantauan komplikasi lebih lanjut.

\section{DAFTAR PUSTAKA}

Arenas MD, Malek T, Álvarez-Ude F, Gil1 MT, Moledous A, ReigFerrer A, 2010, Phosphorus binders: preferences of patients on haemodialysis and its impact on treatment compliance and phosphorus control, Nefrologia, 30(5), 522-30.
Ashley C, Morlidge C, 2008, Introduction to renal therapeutics, Cambridge University Press, London, 38-41.

ASKES, 2010, cited 5 Desember 2011, available from: 
http://www.ptaskes.com/dpho.

Coladonato JA, 2005, Control of hyperphosphatemia among patients with ESRD. Journal of the American Society of Nephrology, 16, S107-S114.

Dipiro JT, Talbert RL, Yee GC, Matzke GR, Wells BG, Posey LM, 2008, Pharmacotherapy : a pathophysiologic approach, $7^{\text {th }} \mathrm{ed}$, McGraw-Hill, New York.

Ekman M, Reizenstein P, Teigen SW, Ronneberg R, 1991, Comparative absorption of calcium from carbonate tablets, lactogluconate/carbonate effervescent tablet, and chloride solution. Bone, 12(2), 93-7.

Hutchison AJ, 2009, Oral phosphate binders, International Society of Nephrology.

Indian Health Service National Pharmacy and Therapeutics Committee, 2010, Phosphate binders used in chronic kidney disease

Karamanidou C, Clatworthy J, Weinman J, Horne R, 2008, A systematic review of the prevalence and determinants of nonadherence to phosphate binding medication in patients with end-stage renal disease, BioMed Central Nephrol, 9 (2), 1-10.

Medscape Pharmacist education, 2010, cited 2011 November $23^{\text {th }}$ available from http://www.medscape.org/viewarticle/724252 3.

National Institute of Diabetes and Digestive and Kidney
Diseases, 2005, Renal Osteodystrophy, NIH Publication, 054630 .

O'Callaghan CA, 200o, The renal system at a glance, $2^{\text {nd }}$ ed., Blackwell, Oxford, 94-95.

PERNEFRI, 2009, Konsensus gangguan mineral dan tulang pada penyakit ginjal kronik (GMT-PGK), edisi 1.

Qunibi W, Winkelmayer WC, Solomon R, Moustafa M, Kessler P, Ho $\mathrm{CH}$, et al., 2011, A randomized, double-blind, placebocontrolled trial of calcium acetate on serum phosphorus concentrations in patients with advanced nondialysis-dependent chronic kidney disease, BioMed Central Nephrology, 12:9.

Sweetman SC, Blake PS, McGlashan JM, Neathercoat GC, Parsons AV, Brayfield A, 2007, Martindale: The Complete Drug Reference, $35^{\text {th }} \mathrm{Ed}$, The Pharmaceutical Press, London.

Thomas SA, 2000, How to write health sciences papers, dissertation and theses, Churchill livingstone, New York.

U.S. Departement of Health and Human Services Food and Drug Administration Center for Drug Evaluation and Research (CDER), 2000, Guidance for Industry: Bioavailability and Bioequivalence Studies for Orally Administered Drug ProductsGeneral Considerations, Center for Drug Evaluation and Research (CDER).

Williams III RO, Taft DR, McConville JT, 2008, Advanced Drug Formulation Design to Optimize Therapeutic Outcomes, Informa Healthcare USA, New York, 227. 